\title{
OS SERTÕES E FACUNDO: DUPLOS
}

\section{OS SERTÕES AND FACUNDO: DOUBLES}

\author{
Josalba Fabiana dos Santos ${ }^{*}$
}

RESUMO: Este trabalho compara Os sertões (1902), de Euclides da Cunha, com Facundo (1845), de Domingo F. Sarmiento. Além dos pontos de contato existentes - alguns serão apresentados -, destacar-se-á a relação entre os textos a partir da ideia de que um é duplo do outro, um repete o outro sem deixar de ser diferente. Para tanto, será evocado Diferença e repetição (1968), de Gilles Deleuze, livro-chave aqui para pensar a identidade e a alteridade entre os textos.

PALAVRAS-CHAVE: Os sertões, Facundo, duplo, civilização, barbárie.

ABSTRACT: This paper aims to compare Euclides da Cunha's Os sertões (1902) with Facundo (1845) by Domingo F. Sarmiento. Some common features will be presented, but major emphasis will be placed on the relationship between the texts from the viewpoint that one is the double of each other, they repeat each other while remaining different. Therefore Gilles Deleuze's Difference and Repetition (1968) will be taken as the main theoretical reference due to its key role in the discussion about the relation of identity and alterity between both texts.

KEYWORDS: Os sertões, Facundo, double, civilisation, barbarism.

* Universidade Federal de Sergipe (UFS), São Cristóvão/SE. Professora Adjunta. Doutora em Letras: Estudos Literários, pela Universidade Federal de Minas Gerais (UFMG). Email: josalba@ufs.br. 



\section{OS SERTÕES E FACUNDO: DUPLOS}

Os sertões: Campanha de Canudos (1902), de Euclides da Cunha, e Facundo: civilização e barbárie (1845), de Domingo F. Sarmiento, são narrativas que mantêm entre si diálogo intenso. Não se trata aqui de provar se o autor brasileiro leu ou não o clássico argentino, mas de demonstrar algumas das aproximações e distanciamentos existentes entre essas duas obras e de se pensar para além de temas ou visões que se repetem ou se diferenciam, mas no próprio ato de distanciar e/ou repetir. Já que ambos os textos têm elementos em comum e que ao mesmo tempo os diferenciam - fator que faz justamente que sejam singularidades a despeito das semelhanças -, o que se pretende abordar aqui é a duplicidade entre eles. O leitor e a leitora ouvem/leem um diálogo entre os dois textos porque um é duplo do outro. O Facundo anuncia Os sertões e Os sertões anuncia o Facundo. Todo duplo presume diferença e repetição: "A diferença habita a repetição" (DELEUZE, 2000, p. 149). O duplo é toque $e$ distanciamento, isto $e$ aquilo - e não isto ou aquilo.

Berthold Zilly, estudioso alemão que tem se dedicado ao texto euclidiano, já fez uma aproximação bastante produtiva entre Facundo e Os sertões, elegendo como chave de leitura a civilização e a barbárie - o título de um dos seus artigos é "A barbárie: antítese ou elemento da civilização? Do Facundo de Sarmiento a Os sertões de Euclides da Cunha" (ZILLY, 2001).

O presente trabalho parte de algumas possíveis respostas à pergunta do título de Berthold Zilly: a barbárie seria o fantasma da civilização; ou a bar- 
bárie assombraria a civilização; ou a civilização é que assombraria a barbárie. A ordem não importa, o que importa é que este binômio é indissociável: a civilização engendra a barbárie e vice-versa. $\mathrm{O}$ antagonismo limita-se à aparência, porque uma pressupõe a outra. A civilização não é nem pode ser o contrário da barbárie porque advém dela mesma. Walter Benjamin atesta isso: "Nunca houve um monumento da cultura que não fosse também um monumento da barbárie" (1993, p. 225).

Afirmar que a barbárie assombra a civilização é o primeiro e talvez mais abrangente duplo em Os sertões e em Facundo: o do fantasma. Todo fantasma é um duplo. Esta é uma premissa fundamental - apesar de nem todo duplo ser necessariamente um fantasma. Um fantasma é um ser que sofreu uma morte ruim (morreu antes da hora ou de forma trágica). ${ }^{1}$ Portanto, ele não está mais vivo, mas tampouco está completamente ou devidamente morto: sua alma está suspensa. Se ele não é mais o vivo que foi nem é ainda o morto que deveria ser, mas remete à pessoa que foi na imagem, na voz e nos gestos, ele é um duplo de si próprio. Com a civilização e a barbárie, como se verá, o caso é similar. A barbárie é um fantasma da civilização e vice-versa, porque há elementos de uma na outra. Todo ato civilizado dissimula um outro bárbaro.

\section{A intertextualidade e o duplo}

A relação entre dois textos pode ser uma atitude de produção deliberada do(a) escritor(a), mas também pode ser um ato de recepção. Neste último caso, a intertextualidade estaria presente no(a) leitor(a), o que não exclui nem inclui necessariamente a possibilidade de o(a) autor(a) ter optado por aproximar seu texto de outro. De qualquer forma, mesmo que haja intertextualidade na produção, se ela não for percebida pelo(a) leitor(a), seu efeito se anulará. Somente a intertextualidade vista/lida é realmente válida, fora isso ela será apenas uma potencialidade: talvez se perceba a intenção do autor, se intenção houve. É na leitura que se concretiza a intertextualidade. É a leitura que produz de fato o duplo de um texto no outro.

Quando o(a) leitor(a) lê um texto no outro, este(a) leitor(a) inscreve um no outro, imprime um sobre o outro, fazendo com que um reproduza o outro. Reprodução que não se dá no mesmo, no igual, mas na repetição de al-

1 Cf. este tema, o do fantasma, in: SANTOS, J. F. A paródia como fantasma. Revista Brasileira de Literatura Comparada, v. 14, 2009, p. 227-245. 
guns pontos de contato para a diferença de vários outros: "A mais exata repetição, a mais rigorosa repetição, tem, como correlato, o máximo de diferença" (DELEUZE, 2000, p. 39). É desta leitura feita de memória - porque só a memória possibilita que o(a) leitor(a) relacione um texto a outro - que emana o duplo. Um texto é duplo do outro porque está impregnado da memória do outro. A leitura de um lembra a leitura do outro; ambos lembram um ao outro, revivem-se um no outro. Ao se lembrar do que um repete do outro, automaticamente lembra-se do que neles se diferencia. Sendo assim, não importa qual foi o primeiro texto publicado, nem mesmo a ordem de leitura faz diferença, porque ao ler um, lê-se o outro e isso se dá concomitantemente. No ato da leitura, o texto não emana de outro texto, ele é com o outro texto.

Se na intertextualidade um texto não emana do outro, mas é com o outro, a discussão sobre a originalidade ou a precedência de um em relação ao outro é totalmente inócua. Comentando Pierre Klossowski, Deleuze afirma: "O eterno retorno, tomado no seu sentido estrito, significa que cada coisa só existe retornando, cópia de uma infinidade de cópias que não deixam subsistir original nem mesmo origem" (2000, p. 136). E continua: "O eterno retorno não permite qualquer instauração de uma fundação-fundamento: pelo contrário, ele destrói, engole todo o fundamento como instância que estabeleceria a diferença entre o originário e o derivado, a coisa e os simulacros" (2000, p. 137). Tais afirmativas são perfeitamente aplicáveis à intertextualidade, pois um texto retorna no outro, indiferentemente de qual tenha sido publicado primeiro.

Em geral, o duplo retira sua existência daquele que duplica, enfraquecendo-o. Otto Rank (2001, p. 17) afirma que o duplo expõe o problema da ameaça de morte. Na verdade, Rank vai ainda além, pois trata do caráter ambíguo. O homem, segundo ele, percebeu que a imortalidade era coletiva e não individual; assim, para se proteger disso, criou o duplo (2001, p. 126). $\mathrm{Na}$ intertextualidade o duplo não é morte, é vida. Ao se relacionarem ou ao serem relacionados, os textos são (re)ativados, um (re)ativa o outro. Um texto ganha uma sobrevida ao ser lembrado em outro. Todo texto encaminha-se para o seu fim, para a sua morte, para o esquecimento. Mas a memória reativa-o. Todo texto encena uma morte no seu fim, na sua última página, mas também uma nova vida na sempre possibilidade do seu (re)começo por meio da leitura dele próprio ou da leitura de outro.

Um texto que repete outro já dele se diferencia no momento exato em que o repete. O duplo não é o mesmo, não é o igual. O duplo é a repetição 
e a diferença do outro, mesmo porque não existe repetição sem diferença nem diferença sem repetição. Se se diz que um texto repete outro é porque não é o mesmo, é porque alguma coisa é diferente. E se se diz que um texto é diferente de outro é porque alguma coisa dele se repete no outro. Por isso, Os sertões repete Facundo e Facundo repete Os sertões, sendo um e outro sempre diferentes de um e de outro. Se assim não fosse, ambos não seriam Os sertões e Facundo, duas obras que se repetem - estabelecendo assim uma relação intertextual -, mas que resguardam suas diferenças e garantem suas singularidades.

A intertextualidade só é possível porque se vê um texto no outro - a repetição permite a identidade - e porque um texto nunca é completamente outro - a diferença implica alteridade. A intertextualidade destrói fronteiras entre textos ao mesmo tempo em que as reforça. Ao aproximá-los pelas repetições que se observam, reafirma suas diferenças. A intertextualidade diz onde dois ou mais textos se repetem e onde dois ou mais textos se diferenciam, portanto, ela mostra a porosidade da fronteira, o seu lugar de contatos. Todavia, nem por ser lugar de contatos a fronteira deixa de ser barreira e de evidenciar assim onde o contato termina.

\section{Civilização e barbárie, barbárie e civilização}

Norbert Elias define civilização em termos de:

uma grande variedade de fatos: ao nível da tecnologia, ao tipo de maneiras, ao desenvolvimento dos conhecimentos científicos, às idéias religiosas e aos costumes. Pode se referir ao tipo de habitações ou à maneira como homens e mulheres vivem juntos, à forma de punição determinada pelo sistema judiciário ou ao modo como são preparados os alimentos (1994, p. 23).

Num primeiro momento, como admite Elias, existe uma relação muito forte entre a palavra civilização e a palavra cultura. No entanto, o que as faz diferir é uma questão de juízo de valores. A civilização termina por estabelecer uma gradação nos conhecimentos científicos, nas religiões, no sistema judiciário, nos costumes, na maneira como são preparados os alimentos. A civilização presume uma forma certa e uma forma errada de ciência, de religião, de fazer e executar leis, de costumes, de comer. Ou, no mínimo, uma maneira melhor e uma maneira pior: uma ciência melhor e uma pior, uma religião melhor e uma pior, uma lei melhor e uma pior 
e assim por diante. Isso tudo com a ressalva de que a maneira civilizada é sempre a mais correta, é a melhor, porque enquanto o contrário de uma dada cultura é outra cultura, o contrário de civilizado é bárbaro. Aquilo que não é civilização é barbárie; a primeira pressupõe um sinal positivo; a segunda, um negativo.

Elias ressalta ainda a indissociabilidade entre nação e civilização:

este conceito expressa a consciência que o Ocidente tem de si mesmo. Poderíamos até dizer: a consciência nacional. Ele resume tudo em que a sociedade ocidental dos últimos dois ou três séculos se julga superior a sociedades mais antigas ou a sociedades contemporâneas "mais primitivas". Com essa palavra, a sociedade ocidental procura descrever o que lhe constitui o caráter especial e aquilo de que se orgulha: o nível de sua tecnologia, a natureza de suas maneiras, o desenvolvimento de sua cultura científica ou visão de mundo, e muito mais (ELIAS, 1994, p. 23).

Nenhuma das grandes potências europeias se consolidou sem se valer de movimentos colonialistas pelas Américas, África, Ásia ou Oceania - continentes tidos como bárbaros. Isso salientava na Europa, segundo Elias (1994, p. 64), um sentimento de superioridade - especialmente nas nações que se tornaram conquistadoras - que serviu como justificativa de domínio. $\mathrm{Ou}$ seja, as nações europeias pautavam seus atos imperialistas em dois pontos: eram civilizadas e, portanto, superiores aos inferiores que tentavam dominar e, ao dominar, levavam aos inferiores um pouco da sua própria superioridade ou civilização. $\mathrm{O}$ empreendimento chegou a persuadir, muitas vezes, até os conquistados da necessidade de se submeterem. Entre a pequena intelectualidade existente nos países colonizados, tornou-se comum a ideia de que, ao se repetir o modo de vida europeu, o jovem país se tornaria civilizado. E como esta intelectualidade se sentia atraída pela Europa, e quase sempre havia se formado lá, era natural que estivesse persuadida da civilidade do outro e da própria barbárie. Ou melhor, a barbárie que esta intelectualidade verificava não era propriamente a sua, mas a da população ao seu redor. $\mathrm{O}$ intelectual colonizado tendia a acreditar que ele não era um bárbaro, bárbaro era o outro, o seu conterrâneo, mas não ele. Sarmiento está bastante integrado a esse pensamento reinante no século XIX; Euclides da Cunha também parecia estar. 


\section{As duas obras}

As semelhanças entre Os Sertões: Campanha de Canudos, de Euclides da Cunha, e Facundo: civilização e barbárie, de Domingo F. Sarmiento, são várias: ambos se iniciam com a descrição do meio, passando para uma análise do homem e depois se detendo na rebelião (PRADO, 1997, p. 38). Para além da estrutura narrativa, há uma aproximação histórica entre Facundo e Os sertões, o século XIX, e geográfica, o interior (na Argentina, os pampas e no Brasil, o sertão). O antagonismo entre civilização e barbárie é explícito desde o título no autor argentino e implícito no brasileiro: os sertões apenas pressupõem o seu contrário, a cidade. Isso é o que faz prever o título, mas o conteúdo revelará que para Euclides da Cunha a civilização é uma ausência, um ideal a ser alcançado.

A visão de história do escritor brasileiro é, como cabe a um homem culto do seu tempo, teleológica: "Estamos condenados à civilização" (CUNHA, 1997, p. 84), afirma. Portanto não há conquista possível, só há o cumprimento de uma sentença. Sentença proferida pelo ideal de nação recorrente à época, fechando assim um círculo: civilizar-se para se tornar uma nação; se nação, é porque se civilizou. No entanto, o círculo não se fecha de fato, porque a barbárie é o fantasma da civilização. Esta já pressupõe a existência daquela. E a barbárie não está no outro, naquele que não se civilizou, que não é nação ainda. Ela está (mal)contida nas fronteiras internas da nação. Homi Bhabha deixa isso muito claro quando diz:

Estamos diante da nação dividida no interior dela própria, articulando a heterogeneidade de sua população. A nação barrada Ela/Própria [It/Self], alienada de sua eterna autogeração, torna-se um espaço liminar de significação, que é marcado internamente pelos discursos de minorias, pelas histórias heterogêneas de povos em disputa, por autoridades antagônicas e por locais tensos de diferença cultural (BHABHA, 1998, p. 209-210, grifo do autor).

Bhabha não está falando de civilização, mas de cultura, na verdade de culturas antagônicas que convivem em uma mesma nação. Enfim, algo que Euclides e Sarmiento mostram nos seus textos, mas que lhes é, de certa forma, incompreensível. Naturalmente, ambos são movidos pelos ideais de nação relacionados ao seu tempo, ideais regidos em termos de unidade nacional e que só admitiam fronteiras externas. Portanto, ideais que não previam a nação "dividida no interior dela própria", heterogênea. No momento em que 
os Estados nacionais se formavam, só se admitia a unidade, o muitos como um, o apagamento das diferenças e a defesa da repetição ou identidade.

Segundo Euclides, o tempo distanciaria o Brasil naturalmente da barbárie, quando o negro e o índio (diferenças) se diluiriam no branqueamento (identidade) feito por meio da miscigenação. Daí a necessidade de $O s$ sertões como resgate de um grupo fadado ao fim, como obra de fundação da identidade nacional:

Intentamos esboçar, palidamente embora, ante o olhar de futuros historiadores, os traços atuais mais expressivos das sub-raças sertanejas do Brasil. E fazemo-lo porque a sua instabilidade de complexos de fatores múltiplos e diversamente combinados, aliada às vicissitudes históricas e deplorável situação mental em que jazem, as tornam talvez efêmeras, destinadas a próximo desaparecimento ante as exigências crescentes da civilização e a concorrência material intensiva das correntes migratórias que começam a invadir profundamente a nossa terra (CUNHA, 1997, p. 7, grifo do autor).

Nesse trecho da Nota Preliminar, o autor explicita os prováveis motivos que contribuiriam para o desaparecimento das "sub-raças", entre outros: a situação mental, as exigências da civilização e as migrações. Ora, se "destinadas a próximo desparecimento", as "sub-raças" são fantasmas por antecipação, são um ainda não que já é um quase, antefantasmas; vivos-mortos e não mortos-vivos, ainda. As "sub-raças" das quais Euclides se ocupa seriam compostas de uma miscigenação básica de brancos com índios - o negro participaria pouco dessa composição, apesar de Canudos ter sido também um reduto de ex-escravos (GALVÃO, 2002, p. 56). Esses grupos não teriam capacidade intelectual para acompanhar as alterações impostas pelas forças progressivas da história (sempre teleológicas). Os sertanejos crentes "receberam mal os primórdios de uma modernização” (GALVÃO, 2002, p. 30) forçada pela República, que separou a Igreja do Estado. Com o advento das grandes ondas migratórias que chegaram ao Brasil a partir da segunda metade do século XIX, as populações interioranas mais tradicionais tornaram-se dispensáveis, pois não conseguiram se adaptar nem ao padrão produtivo imposto pelos novos habitantes, nem tampouco ao discurso progressista que os acompanhava.

No entanto, na Nota Preliminar surge a primeira dúvida de Euclides: talvez as "sub-raças" sejam efêmeras; talvez não. Será um questionamento 
inconsciente sobre a visão de um tempo homogêneo e vazio (BENJAMIN, 1993, p. 229), uma flecha que se desloca no mesmo sentido e na mesma direção (o "estamos condenados à civilização"), em um movimento em que causa e efeito se revezam de maneira previsível e monótona? Talvez. Mas o que é civilizado e o que é bárbaro é problematizado quando a intervenção militar no sertão é posta como um crime:

A campanha de Canudos tem por isto a significação inegável de um primeiro assalto, em luta talvez longa. Nem enfraquece o asserto o termo-la realizado nós, filhos do mesmo solo, porque, etnologicamente indefinidos, sem tradições nacionais uniformes, vivendo parasitariamente à beira do Atlântico dos princípios civilizadores elaborados na Europa, e armados pela indústria alemã - tivemos na ação um papel singular de mercenários inconscientes. Além disto, mal unidos àqueles extraordinários patrícios pelo solo em parte desconhecido, deles de todo nos separa uma coordenada histórica - o tempo (CUNHA, 1997, p. 8).

Euclides atribui a culpa do ato criminoso à indefinição étnica, à falta de tradições nacionais e à ausência de uma nação em um sentido europeu, uma nação imbricada com a civilização. Ele critica o parasitismo daqueles que vivem no litoral e, ocasionalmente, parece ignorar que se vale de teorias europeias para compreender o episódio que relata. Note-se ainda que o parasita é uma espécie de vampiro, portanto, ele é um morto-vivo, pois ganha a sua sobrevida da vida que suga do outro. Enquanto as "sub-raças" sertanejas seriam consideradas vivas-mortas, porque fadadas à extinção próxima, os habitantes do litoral seriam mortos-vivos, porque vampiros, parasitas. Logo, não há, a princípio, para Euclides, civilização no Brasil - nem nas sub-raças, porque incapazes intelectualmente, nem tampouco nos habitantes do litoral, porque meros reprodutores da civilização europeia.

Euclides teria um projeto de nação baseado em um Estado republicano que agenciaria o país à civilização. Tal projeto surge como tema subjacente não só do seu livro como do de Sarmiento (ZILLY, 2001). O autor brasileiro acredita que "o seu país ainda não era um país de verdade" (ANDRADE, 2002, p. 8), logo deveria tornar-se um. A proposta de construção de uma identidade nacional em Euclides quase paradoxalmente se volta para o interior. É quase um paradoxo porque na aparência se opõe à civilização, que estaria no litoral. No entanto, sabe-se quanto fez (e faz) parte do imaginário das modernas nações fixarem no interior certa dosagem de essência ou 
de origem. Essa busca de uma espécie de pré-história nacional atesta no mínimo dois pontos: em primeiro, o progresso, a evolução que só pode ser percebida se comparada a um momento remoto anterior; e, em segundo, o estabelecimento de uma tradição, de uma origem que não poderia estar no exterior, fora das fronteiras. Euclides inverte a lógica da valorização do litoral em detrimento do sertão (VENTURA, 1991, p. 55), porque para ele o litoral estaria exposto aos modismos de toda sorte produzidos na Europa (o parasita vivendo à beira do Atlântico).

Todavia, Euclides teve de enfrentar o fato de que o contraste entre a população do litoral e a população do interior era enorme. Enquanto os do litoral se preocupavam em imitar ideias e modos estrangeiros, os do interior padeciam do mais absoluto isolamento.

Fora longo traçar-lhes a evolução do caráter. Caldeadas a índole aventureira do colono e a impulsividade do indígena, tiveram, ulteriormente, o cultivo do próprio meio que lhes propiciou, pelo insulamento, a conservação dos atributos e hábitos avoengos, ligeiramente modificados apenas consoantes as novas exigências da vida. - E ali estão com as suas vestes características, os seus hábitos antigos, o seu estranho aferro às tradições mais remotas, o seu sentimento religioso levado até ao fanatismo, e o seu exagerado ponto de honra, e o seu folclore belíssimo de rimas de três séculos (CUNHA, 1997, p. 114).

Esse momento impregnado de lirismo é um, entre outros, em que o autor de Os sertões expressa um descompasso entre o sertanejo das teorias racistas e o sertanejo que ele viu quando esteve em Canudos como repórter da guerra: se, por um lado, ele descreve um sujeito com "hábitos antigos", "aferro às tradições mais remotas" e o "sentimento religioso levado até ao fanatismo", por outro, também destaca o "exagerado ponto de honra" - que ele admirava! - e o "folclore belíssimo de rimas de três séculos".

No entanto, a diferença entre o "parasita do litoral" e o sertanejo não se restringia à ocupação de espaços diversos. Era como se ocupassem um tempo distinto: de um lado, os que estavam acompanhando - de maneira discutível para Euclides - as modificações pelas quais passava o Ocidente e, de outro, aqueles que ainda aguardavam a redenção sebastianista, verdadeiros fantasmas, porque vivendo no passado. Para além do tempo distinto, o sertanejo estava em um outro espaço. $\mathrm{O}$ isolamento havia contribuído de forma marcante para sua barbárie. Afastado de todos os apelos citadinos, sobravam 
apenas a miséria, a violência e a crença mística exacerbada. A natureza seria um dos maiores responsáveis por esse isolamento. Seu aspecto selvagem e estéril criava seres igualmente selvagens e estéreis. Ela é traçada como hostil, contrária a qualquer empreendimento humano civilizado. No Facundo, de Sarmiento, a natureza também é assim:

se a arte quisesse prestar-lhe seu auxílio, se as forças da sociedade tentassem suprir a fraqueza do indivíduo, as dimensões colossais da obra afastariam os mais empreendedores, e a incapacidade do esforço o tornaria inoportuno. Assim, [...] a natureza selvagem ditará a lei por muito tempo, e a ação da civilização permanecerá débil e ineficaz (SARMIENTO, 1997, p. 69-70).

Desde o "descobrimento", curiosidade e receio se confundem em solo americano. A ignorância cria personagens e enredos fantásticos. O gigantismo dos espaços hiperboliza os mistérios, aumenta o que é desconhecido, dá-lhe proporções monstruosas. O vasto império, pleno de riquezas, também é pleno de espaços desconhecidos, dos quais não se tem ciência, dos quais não se conhecem bem os limites e nos quais as fronteiras se tornam móveis pela sua distante imobilidade. Os sertões tem sua própria dinâmica: a selvageria justifica os repentes agressivos e a esterilidade está presente na estagnação de uma sociedade que não evoluiu ( usa-se essa palavra aqui na perspectiva teleológica de Euclides), perdida na vastidão. Há a esterilidade da terra formando desertos, atuando como presença física que separa aqueles que são capazes de viver em situação-limite daqueles que sucumbem à adversidade. A seca é posta como resultado do mau uso do solo e coloca o homem como inepto. Em contrapartida, o retrato pintado desse mesmo ser refere-se a alguém que conhece o sertão, alguém capaz de ali sobreviver. É por isso que, mesmo bárbaro, "O sertanejo é, antes de tudo, um forte" (CUNHA, 1997, p. 129) - outro descompasso entre o sertanejo das teorias racistas e o sertanejo que Euclides viu.

Sarmiento também está atento às qualidades do morador do interior argentino:

O vaqueano é um gaúcho grave e discreto, que conhece palmo a palmo vinte mil léguas quadradas de planícies, matas e montanhas. É o topógrafo mais completo, é o único mapa que leva um general para dirigir os movimentos de sua campanha. O vaqueano vai sempre a seu lado. Modesto e reservado como 
uma cerca, está a par de todos os segredos da campanha. A sorte do exército, o êxito de uma batalha, a conquista de uma província, tudo depende dele (1997, p. 92-93).

O motivo da presença militar no interior da Argentina não pode ser outro senão o do ato civilizador. Todavia, o seu guia é o seu adversário. O gaúcho que é solicitado para esquadrinhar a campanha porque a conhece é o mesmo que será morto caso não se curve diante do exército e caso não abandone seus modos bárbaros. Nem por isso Sarmiento deixará de ver na Europa toda a fonte de progresso e de civilização. Somente os habitantes das grandes cidades argentinas conseguiam reproduzir o requinte europeu, enquanto no campo atrasado esse mesmo requinte era objeto de piadas:

O homem da cidade veste o traje europeu, vive a vida civilizada tal como a conhecemos em toda parte; ali estão as leis, as idéias de progresso, os meios da instrução, alguma organização municipal, o governo regular etc. Saindo do recinto da cidade tudo muda de aspecto: o homem do campo usa outro traje [...]; seus hábitos de vida são diferentes; suas necessidades, peculiares e limitadas; parecem duas sociedades distintas, dois povos estranhos um ao outro. Ainda há mais: o homem da campanha, longe de aspirar a se assemelhar ao da cidade, rechaça com desdém seu luxo e suas maneiras corteses, e a roupa do cidadão, o fraque, a capa, a sela, nenhum sinal europeu pode se apresentar impunemente na campanha (SARMIENTO, 1997, p. 74).

Assim como Euclides compara o habitante do litoral (leia-se da cidade, pois era no litoral que se localizavam todas as cidades brasileiras de maior vulto) com o do sertão, Sarmiento também compara o morador da cidade ao do campo. Mas enquanto em Euclides o sertanejo é ora "sub-raça", ora "antes de tudo um forte", e o citadino, um mero reprodutor das ideias europeias, para Sarmiento o argentino da cidade é civilizado. O que Euclides vê como desabonador para o citadino (ser simulacro do europeu, um seu duplo, um arremedo), Sarmiento enxerga como mérito. A civilização para Sarmiento está na Europa e na capacidade que o povo americano teria de reproduzi-la, de repeti-la, ao menos quando não é ameaçada pela barbárie do interior. Em linhas gerais, a civilização, no Facundo, é observada apenas em algumas localidades. Córdoba, por exemplo, é 
edificada num curto e limitado recinto, tem todas as aparências de uma cidade européia, a que dão maior realce a multidão de torres e cúpulas de seus numerosos e magníficos templos. A cidade é o centro da civilização argentina, espanhola, européia; ali estão as oficinas de artes, as casas de comércio, as escolas e colégios, os juizados, enfim, tudo o que caracteriza os povos cultos. /A elegância nas maneiras, as comodidades do luxo, as roupas européias, o fraque e a sobrecasaca têm ali seu teatro e seu lugar conveniente (SARMIENTO,1997, p. 73).

Córdoba é uma cidade melhor do que outras na medida em que repete a arquitetura e os modos europeus. Quanto mais ela apaga suas características locais, mais se notabiliza. Para além da cidade, é preciso que o seu cidadão acompanhe o processo civilizador. É justamente a isso que o escritor argentino se refere quando destaca os trajes do habitante de Córdoba: elegantes e requintados. Está claro que a civilização, para Sarmiento, está na Europa e naqueles que a reproduzem. Mas onde está a civilização para Euclides da Cunha?

Segundo o escritor brasileiro, o sertanejo esteve alheio aos cruzamentos e ao esmagamento da civilização (ANDRADE, 2002, p. 319), logo a cultura do interior estaria mais preservada. Não há no sertanejo a mesma inconstância daqueles que estavam "vivendo parasitariamente à beira do Atlântico" (CUNHA, 1997, p. 8). À beira-mar, o brasileiro teria se tornado um sujeito propenso a todos os modismos europeus, teria perdido o caráter, a personalidade. Ao contrário, a população interiorana manteria uma essência íntegra, avessa às transformações porque ignorante delas. Não seria por meio da força bruta que ela se aproximaria do universo da Rua do Ouvidor. Irônico, Euclides da Cunha afirma:

Os rudes impenitentes, os criminosos retardatários, que tinham a gravíssima culpa de um apego estúpido às mais antigas tradições, requeriam corretivo enérgico. Era preciso que saíssem afinal da barbaria em que escandalizavam o nosso tempo, e entrassem repentinamente pela civilização adentro, a pranchadas (1997, p. 279).

O isolamento também contribui para tornar os sertanejos violentos, sem os princípios civilizados que fariam deles, em tese, seres pacíficos e prontos à vida em comunidade. Os sertanejos tinham uma desculpa, o exército não tinha nenhuma. A princípio, os habitantes de Canudos são descritos como 
criminosos e desordeiros; até que a campanha militar toma um aspecto mais brutal do que toda aquela vida levada no arraial poderia representar:

Insulado no espaço e no tempo, o jagunço, um anacronismo étnico [portanto, um fantasma], só podia fazer o que fez - bater, bater terrivelmente a nacionalidade que, depois de o enjeitar cerca de três séculos, procurava levá-lo para os deslumbramentos da nossa idade dentro de um quadrado de baionetas, mostrando-lhe o brilho da civilização através do clarão de descargas (CUNHA, 1997, p. 389).

Talvez por isso Euclides pense na civilização como condenação ("estamos condenados à civilização" é uma frase que ecoa ao longo do livro). Não há saída, não há alternativa. O progresso também é bárbaro. No sertão desértico não há Estado, não há justiça e, assim como o jagunço está livre para praticar suas selvagerias, o exército estará dispensado de qualquer responsabilidade. Afinal, "não havia temer-se o juízo tremendo do futuro. /A História não iria até ali" (CUNHA, 1997, p. 603). O autor brasileiro se coloca como aquele que salvará Canudos do esquecimento, como aquele que revelará essa lacuna da história. Diz ele na Nota Preliminar, sobre a campanha: "E foi, na significação integral da palavra, um crime. /Denunciemo-lo" (CUNHA, 1997, p. 8). Os soldados, com seus julgamentos sumários e suas sentenças brutais, são rebaixados se comparados aos sertanejos - julgamentos e sentenças feitos em pleno sertão e sem direito a qualquer defesa. O livro de Euclides seria essa defesa, mas chega tarde demais. Na caatinga, a força militar se sente à vontade para degolar seus presos: "Tínhamos valentes que ansiavam por essas covardias repugnantes, tácita e explicitamente sancionadas pelos chefes militares. Apesar de três séculos de atraso os sertanejos não lhes levavam a palma no estadear idênticas barbaridades" (CUNHA, 1997, p. 598).

Enquanto os jagunços eram comandados por Antônio Conselheiro, um louco, segundo Euclides, que levou toda uma população para a morte, os militares eram liderados por tipos disciplinados, instruídos, conscientes à exceção de Moreira César, apresentado como um desequilibrado mental. Não havia justificativa para a violência desmesurada. É assim que o jagunço vai tomando ares heroicos: luta contra todas as adversidades do seu meio e mais as impostas pelo exército. Um dos sertanejos, que havia sido capturado, chega à presença dos seus agressores bastante acabrunhado pelo sofrimento e pela fome, de olhar no chão e corpo diminuído. Mas, ao perceber que será morto, se transforma: 
Retificara-se de súbito a envergadura abatida do negro aprumando-se, vertical e rígida, numa bela atitude singularmente altiva. A cabeça firmou-se-lhe sobre os ombros, que se retraíram dilatando o peito, alçada num gesto desafiador de sobranceria fidalga, e o olhar, num lampejo varonil, iluminou-lhe a fronte. Seguiu impassível e firme; mudo, a face imóvel, a musculatura gasta duramente em relevo sobre os ossos, num desempeno impecável, feito uma estátua, uma velha estátua de titã, soterrada havia quatro séculos e aflorando, denegrida e mutilada, naquela imensa ruinaria de Canudos. Era uma inversão de papéis. Uma antinomia vergonhosa... (CUNHA, 1997, p. 601-602).

Aqui o sertanejo é flagrado como um ser altivo, um verdadeiro herói capaz de desprezar seus algozes no momento da sua própria morte, apesar de a comparação ficar no universo da cultura ocidental - "gesto desafiador de sobranceria fidalga" e "velha estátua de titã". Euclides é obrigado a admitir a campanha de Canudos como um crime da suposta civilização contra a suposta barbárie. As ideias de Euclides sobre a propalada cultura branca saem arranhadas de Os sertões. Como defender a Europa se foram as armas (materiais e ideológicas) produzidas lá as responsáveis pela execução daqueles titãs?

Euclides simplesmente não consegue resolver a contradição entre o sertanejo guerreiro e as teses que afirmavam o seu atraso (LIMA, 2000, p. 15). Como homem do seu tempo, ele via a civilização na tecnologia, na ciência e no requinte europeu. Todavia, quando essa civilização massacra os mal-armados e os mal-alimentados sertanejos, realiza-se "uma antinomia vergonhosa”. E essa é uma diferença considerável entre Euclides da Cunha e Domingo Sarmiento. Quem é civilizado e quem é bárbaro é uma dúvida que assola o texto euclidiano e que não parece ter incomodado a Sarmiento.

Para o autor argentino, há dois agentes travando o processo civilizador, os gaúchos (passíveis de redenção pela escola, porque brancos) e os índios (bárbaros impossibilitados de abandonar sua condição, porque não bran$\cos )$. Em relação a estes últimos, Sarmiento diz "que aguardam as noites de luz para cair, qual enxame de hienas, sobre o gado que pasta nos campos e sobre as indefesas povoações" (SARMIENTO, 1997, p. 65-66) e os chama de "vultos sinistros" (SARMIENTO, 1997, p. 66). Alguns anos após a escrita de Facundo, Sarmiento se torna presidente da Argentina e ordena o extermínio dos índios para que eles parem de assombrar a nação (e a civilização que ali 
pretensamente se formava). Ao contrário de Euclides, Sarmiento não só não se envergonha de massacres, como os realiza ele mesmo.

Evidentemente, como defensor da República e, por extensão, do exército, Euclides se sente cúmplice da Guerra de Canudos e, portanto, culpado. Os sertões seria, segundo Walnice Nogueira Galvão, uma "imensa mea culpa coletiva, que, aceita pela ordem vigente, serviu de catarse ao menos parcial para essa consciência” (GALVÃO, 1994, p. 98). A parcialidade na catarse fica evidente pela recorrente metáfora do fantasma (e outras palavras de carga semântica similar). Os sertanejos-jagunços são "vultos fugazes" (CUNHA, 1997, p. 288) para os soldados da força militar. Mesmo mortos, são aterrorizadores, "multidão de espectros..." (CUNHA, 1997, p. 305). Quando o exército atinge Canudos, essa impressão terrível não se modifica; ao contrário, aumenta:

O jagunço, brutal e entroncado, diluía-se em duende intangível. Em geral os combatentes, alguns feridos mesmo no recente ataque, não haviam conseguido ver um único; outros, os da expedição anterior, acreditavam, atônitos e absortos ante o milagre estupendo, ter visto, ressurretos, dois ou três cabecilhas que, afirmavam convictos, tinham sido mortos no Cambaio; e para todos, para os mais incrédulos mesmo, começou a despontar algo de anormal nos lutadores-fantasmas, quase invisíveis, ante os quais haviam embatido impotentes, mal os lobrigando, esparsos e diminutos, rompendo temerosos dentre ruínas, e atravessando incólumes os braseiros dos casebres em chamas (CUNHA, 1997, p. 372-373, grifo do autor).

Se o jagunço é fantasma, além de monstro, ele é duplo, duplo dele mesmo no caso; multiplicado ele se reforça, apavora o adversário porque impalpável e porque duplicado. Quanto mais temido e impalpável, mais justificado se torna seu extermínio. Não eram pessoas que caíam a bala, eram apenas fantasmas.

A inteligência nacional se calou diante do genocídio de Canudos ou não se fez ouvir a contento até o surgimento de Os sertões. Segundo Walnice Nogueira Galvão, os sertanejos foram incorporados à nacionalidade apenas depois de mortos, só então passaram de jagunços a brasileiros, só aí se tornaram irmãos (1994, p. 107), ou "extraordinários patrícios" (CUNHA, 1997, p. 8), nas palavras do próprio Euclides da Cunha. Todavia, essa incorporação post mortem recoloca ou acentua os sertanejos na condição de fantasmas. 
A metáfora do fantasma revela o silêncio, afinal o que pode dizer aquele que nunca foi visto ou que não é mais visto? A invisibilidade do sertanejo-jagunço contribui para sua liquidação sumária. De onde se deduz uma resposta ao provocativo título do livro de Spivak (Pode o subalterno falar?). Não, em Os sertões ele propositalmente não fala, porque de vivo-morto, de "sub-raça" fadada ao desaparecimento, o sertanejo-jagunço passa a morto-vivo. Portanto, sem vida, sem fala; mais um fantasma a assombrar o intelectual brasileiro impossibilitado de firmar o ato civilizador por meio da cultura letrada, impossibilitado porque marcado pela culpa.

\section{Considerações finais}

Há vários pontos em que Facundo e Os sertões se repetem. Ambos tratam de regiões inóspitas e isoladas em seus respectivos países (os pampas e os sertões), ambos tratam dos habitantes dessas regiões e, principalmente, ambos tratam dos conflitos entre o interior e a cidade. É precisamente dessas repetições que emanarão as diferenças. O gaúcho, em Facundo, e o sertanejo, em Os sertões, são apresentados como bárbaros, atrasados. Tal apresentação não impede que em ambos os livros se façam elogios à destreza tanto do gaúcho quanto do sertanejo, mas é uma destreza primitiva, considerada mais no âmbito da intuição do que no do conhecimento intelectual. No entanto, na narrativa euclidiana surgem dúvidas impostas por causa da violência do exército, dúvidas que relativizam o agente da barbárie: o sertanejo ou o militar, quem estaria mais distante da civilização? Os julgamentos e penas aplicados aos jagunços em plena caatinga fazem Euclides questionar as próprias opiniões. Ele se comove e, por extensão, comove a seu leitor. Já Sarmiento não tem dúvidas sobre o lugar e o agente da civilização e o da barbárie. A primeira está nas cidades e naqueles habitantes capazes de reproduzir o modo de vida europeu. Enquanto que a barbárie está nos pampas: tanto nos gaúchos quanto nas populações indígenas.

O gaúcho e o sertanejo são apresentados como coletividades e, portanto, generalidades. Eles são duplos dos seus referentes reais, sertanejos e gaúchos, que por sua vez repetem e se diferenciam dos seus referentes literários. A literatura duplica assim a linguagem sobre o real e não o real propriamente dito. Compagnon é direto sobre essa questão: "Em poesia, um ato de linguagem aparente não é realmente um ato de linguagem, mas somente a mimèsis de um ato de linguagem real" (1999, p. 135) O que é essa mimèsis senão um duplo que se posiciona aquém e além da intertextualidade? Em 
Facundo e em Os sertões, esse movimento de duplicação da linguagem multiplica a força do gaúcho e a do sertanejo para assombrar a civilização. Mas isso não impede que seja a civilização igualmente um fantasma. Afinal, não seria a civilização um mero ideal iluminista/romântico jamais materializado? $\mathrm{O}$ ato civilizatório remete a um modelo, a uma origem em que tudo teria começado. No entanto, não existe origem, apenas cópias.

A repetição é verdadeiramente o que se disfarça ao constituir-se e o que só se constitui ao disfarçar-se. Ela não está sob as máscaras, mas forma-se de uma máscara para outra, tal como de um ponto notável a outro, com e nas variantes. As máscaras nada recobrem, excepto outras máscaras (DELEUZE, 2000, p. 65).

Ou, repetindo ainda uma vez as palavras de Benjamin: "Nunca houve um monumento da cultura que não fosse também um monumento da barbárie" (1993, p. 225).

\section{Referências Bibliográficas}

ANDRADE, Olímpio de S. História e interpretação de Os sertões. 4. ed. Rio de Janeiro: Academia Brasileira de Letras, 2002.

BENJAMIN, Walter. Magia e técnica, arte e política: Ensaios sobre literatura e história da cultura. Trad. Sergio Paulo Rouanet. 6. ed. São Paulo: Brasiliense, 1993. v. 1.

BHABHA, Homi K. O local da cultura. Trad. Myriam Ávila; Eliana Lourenço de Lima Reis; Gláucia Renate Gonçalves. Belo Horizonte: Ed. UFMG, 1998.

COMPAGNON, Antoine. O demônio da teoria: Literatura e senso comum. Trad. Cleonice Paes Barreto Mourão; Consuelo Fortes Santiago. Belo Horizonte: Ed. UFMG, 1999.

CUNHA, Euclydes da. Os sertões: Campanha de Canudos. 38. ed. Rio de Janeiro: Francisco Alves, 1997.

DELEUZE, Gilles. Diferença e repetição. Trad. Luiz Orlandi; Roberto Machado. Lisboa: Relógio d’Água, 2000.

ELIAS, Norbert. O processo civilizador. Rio de Janeiro: Zahar, 1994. v. 1.

GALVÃO, Walnice Nogueira. No calor da hora. 3. ed. São Paulo: Ática, 1994. 
. O império do Belo Monte: Vida e morte de Canudos. São Paulo: Fundação Perseu Abramo, 2002.

LIMA, Luiz Costa. Euclides da Cunha: Contrastes e confrontos do Brasil. Rio de Janeiro: Contraponto; Petrobrás, 2000.

PRADO, Maria Ligia Coelho. Prefácio à edição brasileira. In: SARMIENTO, Domingo F. Facundo: Civilização e barbárie. Petrópolis: Vozes, 1997.

RANK, Otto. Don Juan et le double. Paris: Payot, 2001.

SARMIENTO, Domingo F. Facundo: Civilização e barbárie. Petrópolis: Vozes, 1997.

VENTURA, Roberto. Estilo tropical: História cultural e polêmicas literárias no Brasil, 1870-1914. São Paulo: Companhia das Letras, 1991.

ZILLY, Berthold. A barbárie: antítese ou elemento da civilização? Do Facundo de Sarmiento a Os sertões de Euclides da Cunha. 2001. Disponível em: $<$ www.artnet.com.br/gramsci/arquiv157.htm>. 